\title{
THE 2015 OPERATION TO EVACUATE CHINESE CITIZENS FROM YEMEN
}

\section{Original article}

\section{Autor(s) CC BY 4.0 Licence}

\section{Peer review: \\ Double blind}

\section{Keywords:}

Near East, diplomacy, evacuation of non-military personnel, geopolitics, Non-combatant Evacuation Operation, evacuation

\author{
Robert Pawlicki ${ }^{1}$, Bartłomiej Słomski \\ Military University of Technology in Warsaw, \\ gen. Sylwestra Kaliskiego 2, 01-476 Warszawa
}

\footnotetext{
${ }^{1}$ Plk dr Robert Pawlicki - 1998 graduate of the Stefan Czarniecki Higher Officers School in Poznań. Graduate of the Adam Mickiewicz University, Poznań, where in 1999 he was awarded a master's degree. In the years 2003-2006 a student at the National Defense University, where in 2006 he defended his doctorate. From 2007 to 2018, served in the Military Police structures, holding the positions of junior specialist and head of section at the Mazovian Division of the Military Police, head of the department at the Military Police Headquarters, deputy commander and commander of the Military Police Training Centre in Mińsk Mazowiecki. Served in the military outside the country as part of the fifth and sixth tour of duty of the Polish Military Contingent (PKW) in Afghanistan. From 1 April 2018 the deputy dean of the Faculty of Security, Logistics and Management of the Military University of Technology. Interests include internal security, peace missions and operations, and special forces. Email address: robert_pawlicki@op.pl.

${ }^{2}$ Mjr Bartlomiej Słomski - a graduate of the University of Łódź and the Poznań University of Economics and Business. In 2008 he graduated from the Land Forces Officers' College in Wrocław. Since 2011, he serves in the structures of Military Police. He served in the military outside the country as part of the eleventh tour of duty of the PKW in Afghanistan. Since 7 January 2020, he holds the position of Specialist in the Crisis Management Department of the Operational Center of the Military Police Headquarters. Scientific interests include national and international security, modern armed conflicts and the role the powers play in security. Email address: slomski.bartlomiej@gmail.com.
} 


\section{Introduction}

When we consider our scarce national experience in the implementation of noncombatant evacuation operations it seems justified to analyze the experiences of other nations in this respect. What deserves special attention among the numerous operations of this type carried out in the 20th and 21st centuries, is the 2015 operation of PRC for evacuation of nonmilitary personnel carried out in Yemen. Presenting the actions taken as its part, due to the large numbers of people authorized to be evacuated, the difficult operating theater, and the range of implemented activities will allow us to demonstrate the specifics of evacuation operations. At the same time, although the efficiency of the said operation seems to be model, the subject of it was not yet considered by Polish researchers, and the course of operation remains unknown to the Polish reader. The underlying reasons for this seem to be the specific subject matter as well as the short time that has elapsed since the said evacuation. The present article aims to, at least partially, fill the research gap in this area.

The main purpose of this article is to present the evacuation of Chinese citizens from Yemen in 2015. In this context, the following research issues will need to be addressed:

1. What are the characteristics of non-combatant personnel evacuation operations?

2. What was the operational environment for the performed the evacuation?

3. What were the reasons for the presence of a significant number of Chinese nationals in a high-risk country?

4. What forces were used to carry out the evacuation?

5. What mode of action was selected and what were the key factors that determined that selection?

6. What was the course of execution phase?

7. What objectives did China achieve in the result of the successful evacuation of its citizens from Yemen?

The following research is a study resulting from the analysis of the available source materials. Due to the lack of access to primary sources in the form of Chinese planning and command documents, it was necessary to limit the sources to secondary sources, i.e. primarily English-language publications. 


\section{General characteristics of non-combatant personnel evacuation operations}

The issue of evacuation of non-combatant personnel from abroad is a subject that evades frequent consideration as part of scientific research in Poland, therefore, for the purposes of this article, it is necessary to clarify the meaning of basic terminology related to this type of activities, present their specificity and outline a general implementation scheme.

Evacuation operations, called NEO - Non-combatant evacuation operations, are defined as operations carried out to relocate certain non-combatant personnel, currently at risk in a foreign country, to a safe destination. As a rule, NEOs are managed by heads of diplomatic missions in the respective country, who are the representatives of the state, and are responsible for the safety of nationals of the said country abroad. The military forces only hold a supporting function, and their use is ancillary to evacuation organized through the diplomatic channel. Army is only called in, where the option of evacuation with commercial means of transport is not available, either due to the threat present, or due to the large number of people requiring evacuation. In this context, it is important (in principle) to separate management and command chains in evacuation operations - the head of the diplomatic mission and the military component commander issue orders and instructions to subordinate personnel within the relevant, diplomatic or military chain of command ${ }^{3}$.

The evacuation process runs within a framework of key points, which include:

1. Assembly points - gathering places for authorized persons from which they are transferred to an evacuation point. The assembly points can also be located in evacuation points.

2. Evacuation points - places where the personnel authorized to evacuate is transported for further dislocation.

3. Loading/boarding points - seaport, airport or other place, where loading or boarding of authorized persons takes place. This involves means of transport that are used to relocate them to a safe location.

4. Temporary (nearest) safe place - a place designated in a given area or in another country, to which authorized persons can be quickly and easily transported.

5. Operation command centre - the organizational structure responsible for coordinating the relocation of authorized persons from the threatened areas to a safe place. It has the

\footnotetext{
${ }^{3}$ These principles, set out in the national doctrine of Non-Combatant Personnel Recovery Operations DD-3.4.2 (A) are uniform for all NATO countries. Although China appears to following Western solutions, other countries may not comply with the standards described and have their own procedures in this regard.
} 
ability to check arriving persons in detail, furthermore, it also performs the necessary actions to ensure adequate logistic and medical security. The operation control centre can be located in the country from which the evacuation is carried out, in another country, as well as at sea. One of the possibilities is to arrange the operation control centre in an advanced centre for collection,

6. Advanced preparatory (collection) base - a transitional (temporary) place used to achieve the operational readiness of the forces conducting the evacuation, before moving them to the area of operations.

7. Safe final destination - seaport, airport or other place in the country of origin, designated as the destination for the evacuation of authorized persons.

Figure 1 presents a simplified diagram for the evacuation process.

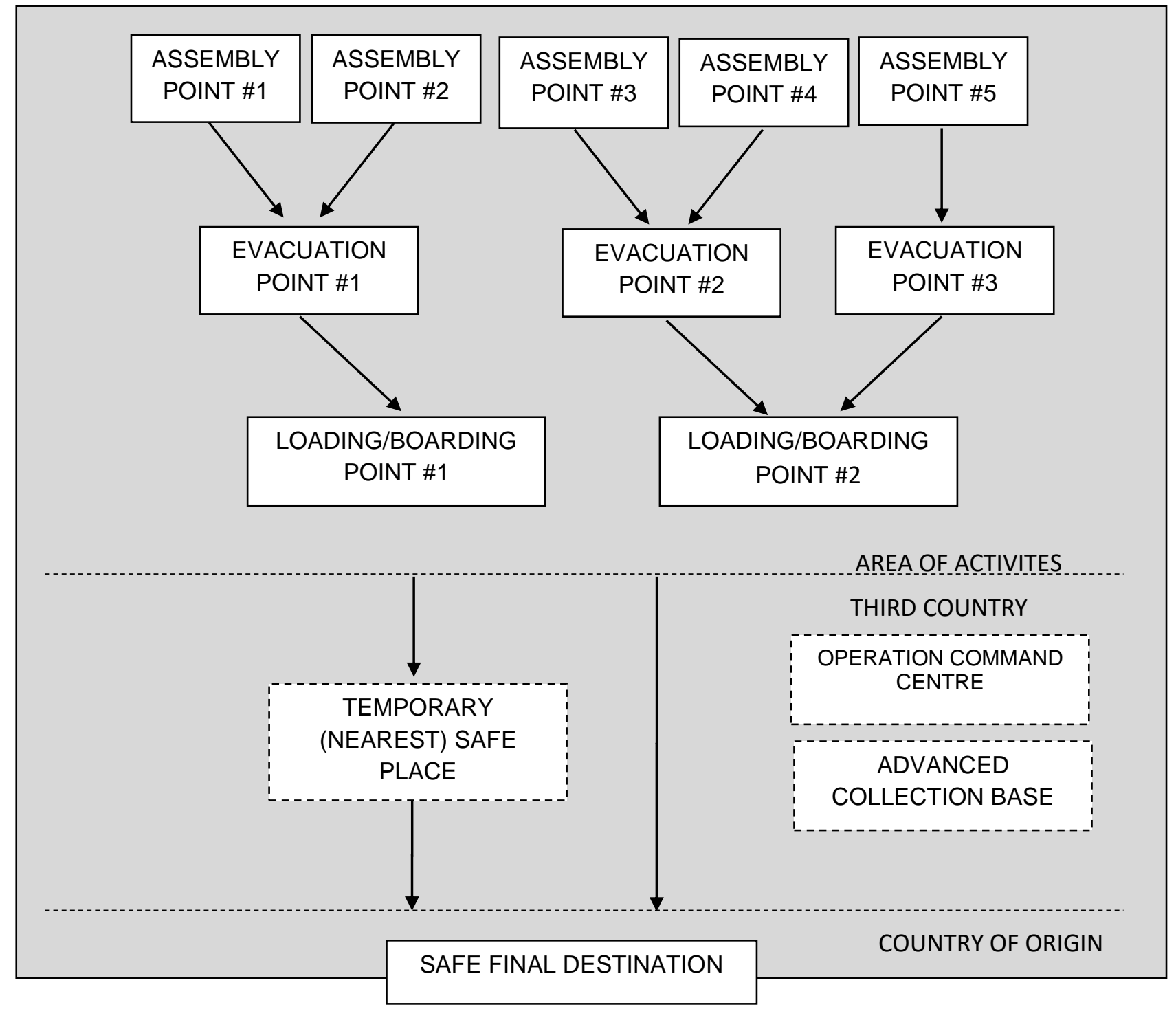

Fig. 1. Simplified diagram of the evacuation process

Source: own elaboration 


\section{Operation environment}

The unrest in Yemen, which forced the 2015 evacuation of citizens of other countries, was not a single conflict in its essence, but a real mosaic of multifaceted local, international (regional and global) conflicts, rooted in both current and past events. Polish readers, with the exception of researchers specializing in the subject of armed conflicts in the Middle East, have rather limited knowledge of these issues, therefore, in order to familiarize them with the environment for evacuation of personnel from Yemen, it is necessary to outline the general characteristics of the conflict, including its genesis.

Geographically, Yemen is located on the southern, most mountainous part of the Arabian Peninsula and it is divided into four regions. The Asir Mountains and their foothills occupy the western part of the country. The semi-desert Tihama coastal plain runs between the Red Sea and the said mountain range. The northeastern part of the country is occupied by Ar-Rab al-Chali, the world's largest sandy desert, also known as the "Empty Quarter". The Coastal Mountain range runs through the southern part of Yemen and is lower than mountains in the interior of the country ${ }^{4}$. The described geographical conditions of Yemen had a decisive impact on its socio-political shape. For centuries the northwestern, mountainous part of the country w inhabited for by the self-ruling Zaydi (Shiite) tribes. The south-eastern part, is inhabited mainly by Sunnis, and for many years it was under British colonial control. In the result of separatist activities, as well as the Suez crisis, on 30 October 1967, the British left South Yemen ${ }^{5}$. After several years of internal fighting, Arab socialists supported by the USSR finally came to power in South Yemen. The resulting People's Democratic Republic of Yemen closely cooperated in military and economic terms with the Soviet Union (Orkaby, 2014, p. 296). As a consequence, North Yemen was placed under the political and financial protection of Saudi Arabia and the United States. Both states were hostile towards each other, they even conducted short-term military actions, but without a decisive victory of neither of the belligerents. Towards the end of USSR's existence the South Yemen, now devoid of financial support, began to plunge in economic crisis, which lead to its quick unification with North Yemen (Rego, 2018, p. 73). In November 1989, a unification declaration was signed, according to which half a year later, on 22 May 1990, both Yemeni states formed the Yemen Republic (Amber, 1999, p. 170). Despite the unification of the country, the inhabitants of Yemen defined themselves in denominational and tribal categories, rather than civic-political

\footnotetext{
${ }^{4}$ National Intelligence Survey, Yemen (Aden), July 1973, p. 1.

${ }^{5}$ Ibidem, p. 3.
} 
ones. In addition to southern secessionist tendencies, internal tribal separatisms were strongly present in the country. Religious tensions between Shiites and Sunnis was also becoming more pronounced. Although the conflict between these two factions of Islam lasted from its very beginnings, in Yemen their followers have, for centuries, learned to live in peace with each other. This situation changed on the face of the wave of radicalism that swept through the Muslim world at the turn of the 20th and 21st centuries.

In 2011, after nine months of public protests, president Ali Abdullah Saleh, the first president of united Yemen, resigned from the office he has held for 22 years. The resignation of the president was the result of a consensus of international forces, where Saudi Arabia played the crucial role. Its purpose was to remove the looming danger of civil war in a country that was on the brink of collapse. Once Yemen failed to introduce the expected reforms, and the political situation begun to return to its old paths, the old divisions also revived. When in 2014 the Shiites from north, called the Houthis, allied with the former president Saleh, and the part of Yemeni army that was still loyal to him, were removed from power, they occupied the capital of Yemen, Sana'a. In January 2015, in order to force the resignation of the incumbent President Abdrabbuh Mansur Hadi, Houthis stormed the presidential palace and occupied key government buildings. President Hadi fled to Aden and then to Saudi Arabia to lead the country from there (Darwich, 2018, p. 6). The subsequent Houthi offensive got stuck, when they entered the southern and western areas controlled by Sunnis, and the hostile tribal confederations, or Al-Qaeda fighters ${ }^{6}$.

The abovementioned Al-Qaeda largely benefited from chaos in Yemen for many years. Both in 2015 and continuing to the present day it is a significant military force in Yemen. Even before 11 September 2001, the country was one of Al-Qaeda's organizational and planning centres. It was in Yemen, not long after the organizational consolidation, that Al-Qaeda made its first unsuccessful attacks aimed at American soldiers transferred to Somalia $^{7}$. The organization's most-known attacks on Yemen's territory included the 2000 US terrorist attack on the USS Cole moored in the port of Aden, which killed 17 seamen, and the terrorist attack on the US embassy in Sana'a in 2008. The activity of this organization is further proved by its activities abroad, which include the attempt to bomb the Northwest

\footnotetext{
${ }^{6}$ Yemen's western-backed president flees house arrest in Sana'a [online] 21/02/2015, https://www.theguardian.com/world/2015/feb/21/yemens-western-backed-president-flees-house-arrest-in-sanaa [access: 30/12/2019].

${ }^{7}$ S. MacLeod, In Yemen, a Massacre of Americans Is Averted [online] 17/09/2008, http://content.time.com/time/world/article/0,8599,1842045,00.html [access: 30/12/2019].
} 
Airlines plane in $2009^{8}$, and the 2015 attack on the headquarters of the Charlie Hebdo satirical magazine ${ }^{9}$. The significance of the Yemeni branch of Al-Qaeda is also reflected in the fact that in November 2008 there were as many as 101 Yemeni inmates in the Guantanamo camp (Boucek and Johnsen, 2010, p. 26). The long lasting attempts of Yemen's authorities to eradicate Al-Qaeda brought no success. It was not the Yemeni authorities that were targeted by the terrorist organizations, but the Western countries. Hence, the rulers of Yemen preferred to focus on suppressing the Houthis rebellion and southern separatisms, and the fight against terrorism was put aside (Hedberg, 2010, p. 70).

When the Shiite Houthis rebels seized Aden in March 2015, the incumbent Yemen president fled to Saudi Arabia, and the Saudis faced the threat of completely losing control over the events in Yemen. They decided to take military action to restore Hadi to power. On 25 March 2015, Saudi Arabia launched, on its own, a military intervention in Yemen under the code name "Breakthrough Storm". A few hours later, eight Arab countries - Egypt, Bahrain, Kuwait, Qatar, United Arab Emirates, Jordan, Sudan and Morocco - declared their participation on the Saudi part of the operation (Darwich, 2018). A joint statement issued in Riyadh by the countries forming the Gulf Cooperation Council (with the exception of Oman that neighbors Yemen) claimed that the intervention was at the request of the Hadi government ${ }^{10}$. The declared objectives of the operation were to restore President Hadi to power, protect the integrity of their own southern border, prevent Yemen from collapsing, and stop Iran's growing influence in the region. The United States did not elect to participate directly in the campaign, merely providing the coalition with logistical and intelligence support $^{11}$.

In 2015 the Chinese citizens residing in Yemen were not a direct target in the ongoing conflict, but they could fall victims of an accidental attack, all the more so since neither party to the conflict had complete control over the territory and the population of the country. The

${ }^{8}$ B. Riedel, Al Qaeda's Yemen Connection, America and the Global Islamic Jihad [online] 30/12/2009, https://www.brookings.edu/blog/up-front/2009/12/30/al-qaedas-yemen-connection-america-and-the-globalislamic-jihad/ [access: 30/12/2019].

${ }^{9}$ Al-Qaeda in the Arabian Peninsula (AQAP) [online] 19/06/2015, https://www.cfr.org/backgrounder/al-qaedaarabian-peninsula-aqap [access: 30.12.2019].

${ }^{10}$ Saudi and Arab allies bomb Houthi positions in Yemen [online] 26/03/2015, https://www.aljazeera.com/news/middleeast/2015/03/saudi-ambassador-announces-military-operation-yemen150325234138956.html [access: 30/12/2019].

11 White House Spokesperson statement of 25 March 2015 [online] 25/03/2015, https://obamawhitehouse.archives.gov/the-press-office/2015/03/25/statement-nsc-spokesperson-bernadettemeehan-situation-yemen [access: 30/12/2019]. 
aforedescribed conditions prove that the operational environment, in which Chinese military and diplomats had to operate, should be deemed uncertain. What's more, the dynamics of the development of the situation indicated the possibility of transforming the operating environment from uncertain to hostile. 


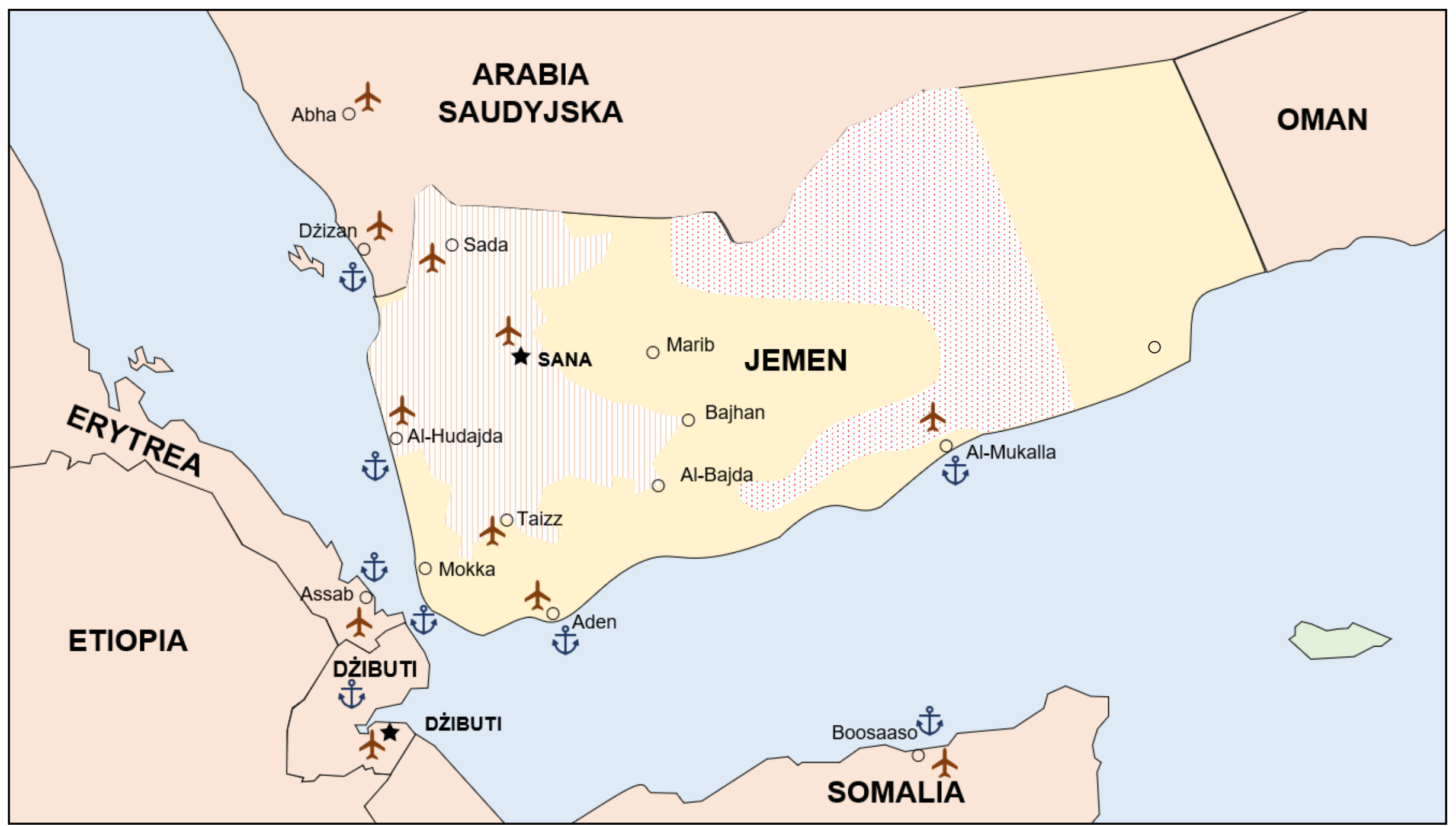

Fig. 2. Civil war in Yemen. Areas controlled by the parties to the conflict at the beginning of March 2015 (approximate)

Source: own elaboration 


\section{Chinese presence in Yemen}

Yemen, although economically backward and torn apart by the civil war, was a country with great development potential and thus enjoyed considerable interest from China. The oil industry became the main axis for construction of Beijing-Sanaa economic relations. The growing consumption of oil has turned China's attention not only to the main suppliers of this raw material, but also to its marginal producers, including Yemen. Although the country's oil reserves are much lower than that of its neighbors, in 2005 Chinese corporations begun exploration and production operations. Estimates indicate that in 2014 Chinese enterprises extracted around 20,000 barrels of crude oil a day in Yemen ${ }^{12}$. Beijing's determination to operate in this sector was so large that mining companies continued to work in Yemen, despite the growing threat. Economic relations between the countries were maintained regardless of the chaos that prevailed at the beginning of 2015 and the removal of Hadi from the office, and oil supplies from Yemen continued to reach China. In the face of the collapse of the existing state structures after Houthis occupied Sanaa, the Chinese government adopted a pragmatic approach, conducting economic talks with their leaders. According to estimates, the level of oil supply in the first two months of 2015 was $315 \%$ higher than in the corresponding period of the previous year ${ }^{13}$.

The situation escalated after 26 March 2015, in the result of the begin of military operations against Houthis by the coalition countries. In the face of imminent danger, over the next few days, most countries and international organizations decided to evacuate their personnel from Yemen. By 28 March 2015, dozens of foreign diplomats and UN staff were evacuated from Yemen with the aid of the Saudi Arabian Navy. Furthermore, some 100 foreigners working for the UN and international oil companies departed from the airport in Sanaa to Ethiopia and Djibouti ${ }^{14}$. In the following days, to ensure the security of its own citizens, China and 7 other countries organized evacuations of their citizens from Yemen. On the eve of the evacuation, the Chinese ambassador in Yemen Tian Qi estimated that some 590 Chinese citizens would be entitled to it. This group included diplomatic staff, foreign

\footnotetext{
${ }^{12} \mathrm{M}$. Z. Rakhmat, Why Is China Interested in a Volatile Yemen? [online] 04/06/2014, https://thediplomat.com/2014/06/why-is-china-interested-in-a-volatile-yemen/ [access: 30/12/2019].

${ }^{13}$ A. Taylor, What Yemen's crisis reveals about China's growing global power [online] 31/03/2015, https://www.washingtonpost.com/news/worldviews/wp/2015/03/31/what-yemens-crisis-reveals-about-chinasgrowing-global-power/ [access: 30/12/2019].

${ }^{14} \mathrm{~L}$. Sabin, Foreign diplomats and UN workers evacuated from Yemen amid bloodshed between Shia Houthis and Sunni fighters [online] 28/03/2015, https://www.independent.co.uk/news/world/middle-east/foreigndiplomats-and-un-workers-evacuated-from-yemen-amid-bloodshed-between-shia-houthis-and-sunni10141049.html [access: 30/12/2019].
} 
exchange students, 58 medical workers, three journalists, and the technical staff of oil, telecommunications and other companies ${ }^{15}$.

\section{Selection of forces and command}

The selection of forces used to evacuate non-combatant personnel is determined primarily by the environment in which the operation will be conducted. In a favourable environment, operations can be carried out by forces currently present in such country. In an uncertain or hostile environment, evacuation may require appropriate adaptation of structures, forces and ways of developing them to the situation in the theater of operations. Although the operational environment of Yemen was uncertain, the Chinese decided not to transfer any further military forces to the Near East, and to use the forces already operating in the area, in the form of the naval task force conducting anti-piracy actions in the Gulf of Aden, to perform the NEO. This force, consisting of continuously rotating patrols that were initiated in the Gulf of Aden, and off the coast of Somalia in October 2008, conducted 20 convoy operations between 2009 and $2015^{16}$. The composition of the battle group has solidified in the course of operations and has remained unchanged for years: two frigates supported by one supply unit. In March 2015 the Gulf of Aden was patrolled by the 19th Escort Group of the Chinese Navy, consisting of two type 054A frigates: Weifang and Linyi and a type 903 supply ship Weishanhu ${ }^{17}$. The presence of a small force of marine special forces, which could be used to secure the loading (boarding) points, evacuation points or routes of transport, was another advantage. The frigates were also equipped with Harbin Z-9C onboard helicopters, and each of them could be used to airlift groups of up to 10 soldiers, including fast-roping them.

The command structure was implied by selection of forces. Rear admiral Jiang Gouping was appointed the commander of the aforesaid task force, and the operation command centre was located at sea ${ }^{18}$.

\footnotetext{
${ }^{15}$ Warship arrives to evacuate Chinese nationals from Yemen [online] 30/03/2015, http://www.ecns.cn/2015/0330/159903.shtml [access: 30/12/2019].

${ }^{16}$ D. Sun, China's Soft Military Presence in the Middle East, Riyadh 2018, p. 5.

${ }^{17}$ A. Erickson, A. Strange, Six years at sea... and counting: Gulf of Aden anti-piracy and China's maritime commons presence, Washington 2015, p. 90.

${ }^{18}$ J. Perlez, Rescue Mission in Yemen Proves to Be Boon for Chinese Military's Image [online] 08/04/2015, https://sinosphere.blogs.nytimes.com/2015/04/08/rescue-mission-in-yemen-proves-to-be-boon-for-chinesemilitarys-image/ [access: 30/12/2019].
} 


\section{Evacuation method}

The operational environment described in the previous part of the article was not only the main factor determining the structure of forces planned to carry out the evacuation, but also determined how to apply them. Due to ongoing warfare, evacuation by land to neighboring countries - Saudi Arabia and Oman - was excluded from the possible ways of implementation. At the same time, due to the large number of people expected to evacuate and air uncertainty, also evacuation by air did not seem be the optimal solution and failed to gain acceptance in Chinese decision-making circles. The decision to carry out the evacuation using the Chinese fleet operating in the area forced the necessity to carry out evacuation from the Yemen littoral zone, based on boarding points located in local seaports. Consequently, the evacuation could be carried out immediately, without having to construct a new contingent of forces at the theater of operations. At the same time, this meant giving up the option of conducting evacuation directly from the hazardous area to the country of origin. Boarding a significant number of civilians and returning to the home country with them would mean that the Chinese navy would abandon its patrolling tasks. Therefore another solution was adopted, i.e. the evacuation of civilians by sea only to the so-called nearest (or temporary) safe place, and then their transport to the destination in the country of origin, using commercial means of transport. The adopted concept enabled the evacuation to be carried out with only a short suspension of patrol operations of the Chinese contingent.

Eventually, the Chinese selected Djibouti as the temporary safe place. The port of Djibouti was the nearest large safe port near Yemen. What was also essential, this small country not only holds a seaport, but also the large civilian-military Ambouli airport, capable of supporting international flight operations. It should also be remembered that there was also a favourable political climate in Djibouti towards China, and mutual relations of the countries extended far beyond commercial activities. Earlier, due to its geostrategic significance, Djibouti was selected as one of the key locations for the implementation of the Chinese BRI - Belt and Road Initiative. What is also worth stressing is that this port was familiar to the Chinese seamen, as in January 2015 the Chinese escort group used it to collect its supplies from $^{19}$. The 25 February 2014 partnership agreement for the areas of safety and defense,

${ }^{19}$ D. Wingrin, Chinese anti-piracy frigate docks in Djibouti [online] 28/01/2015, https://www.defenceweb.co.za/security/maritime-security/chinese-anti-piracy-frigate-docks-in-djibouti/ [access: 30/12/2019]. 
under which the Chinese army could use the military and logistics infrastructure, and in particular the port infrastructure, was of an additional advantage ${ }^{20}$.

Two Yemeni ports located in a short distance from Djibouti were selected as boarding points from where the Chinese citizens were to be transported to the temporary safe place: the port of Aden and the port of Al-Hudaydah (the distance between the ports of Djibouti and Aden is $248 \mathrm{~km}$, and between Djibouti and Al-Hudaydah $355 \mathrm{~km}$ ). The location of boarding points in the coastal zones made it necessary to transport the evacuees by land, from the interior of the country, which could have a negative impact on their safety.

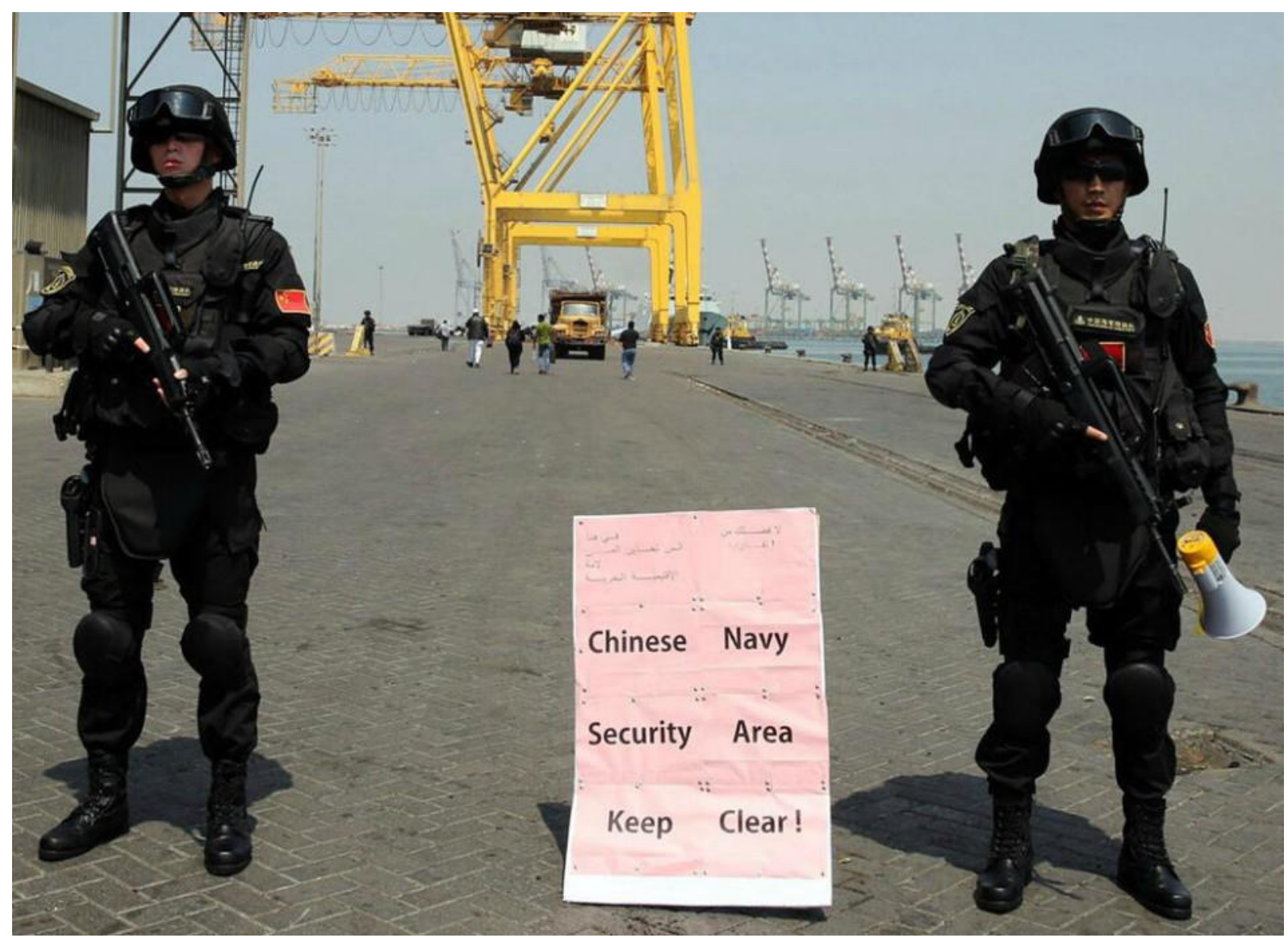

Fig 3. Chinese special forces soldiers, uniformed in a manner characteristic of the contingent operating in the Gulf of Aden, secure the waterfront at the temporary safe place in Djibouti

Source: Xinhua News Agency. [online] 2015/04/04, https://xw.qq.com/cmsid/2015040500500300 [access: $30 / 12 / 2019]$

\footnotetext{
${ }^{20}$ Djibouti and China Sign a Security and Defense Agreement [online] 27/02/2014, https://allafrica.com/stories/201402280055.html [access: 30/12/2019].
} 


\section{The course of activities during the execution phase}

The execution phase began on 29 March 2015, when the first group of 122 Chinese citizens was evacuated from the port of Aden to the temporary safe place in Djibouti. A day later, the evacuation of another 449 Chinese citizens who, at that time, were employees of twelve Chinese enterprises operating in Sanaa, followed. In addition to Chinese citizens, the evacuated group also included eight foreigners employed by Chinese companies. The evacuees first took a five-hour journey from the evacuation point in Sanaa to the boarding place in Hudaydah by their own means of transport, or by buses organized by the embassy. There, they boarded the PRC Weifang frigate, and were then transported by sea to Djibouti ${ }^{21}$.

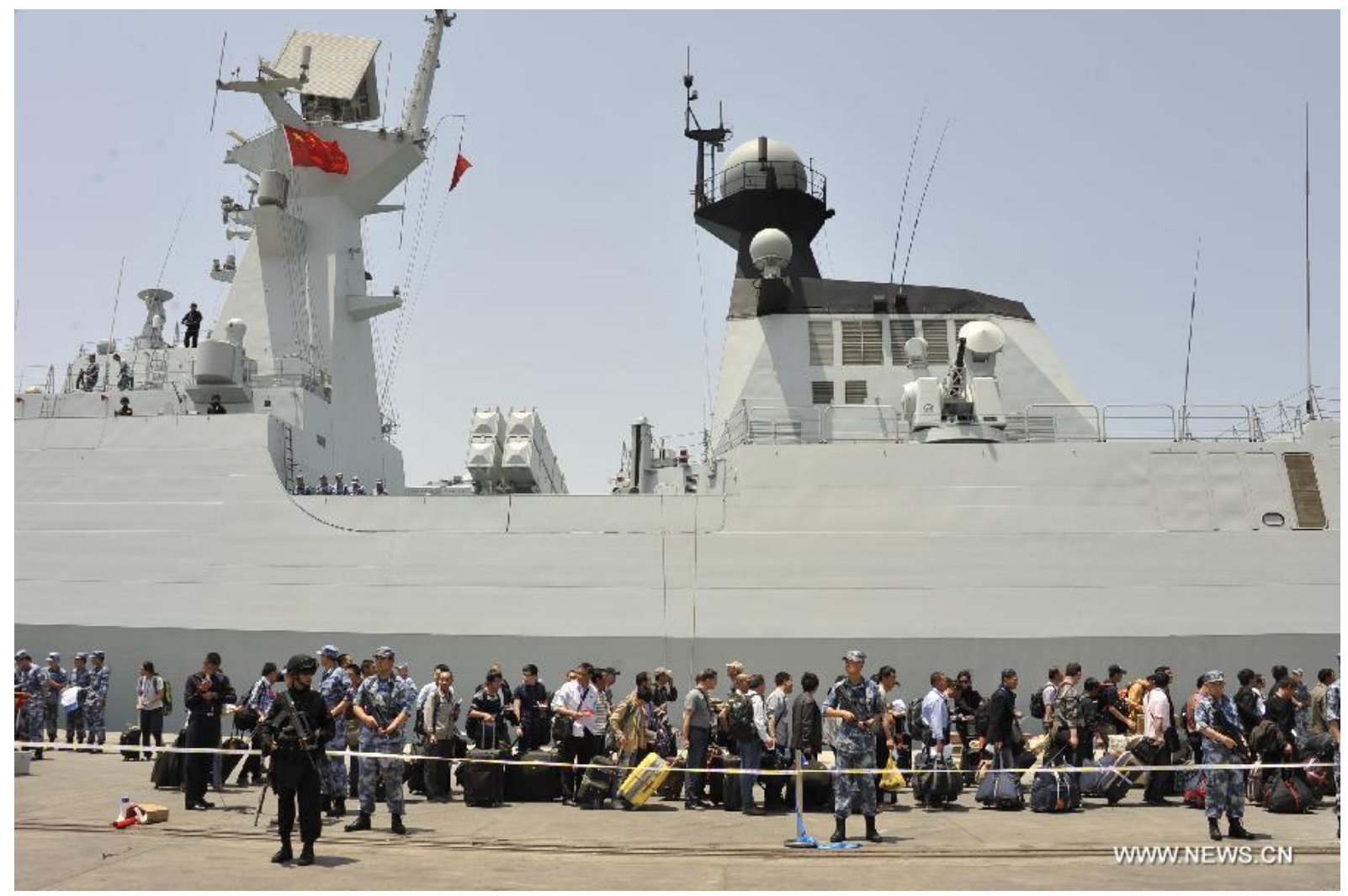

Fig. 4. Chinese citizens awaiting in line to board at the port of Aden. 2 April 2015

Source: Xinhua Information Agency [online] 2015/04/07,

http://english.www.gov.cn/news/photos/2015/04/07/content_281475084609493.htm [access: 30.12.2019]

${ }^{21}$ China Global Television Network coverage entitled China evacuates Chinese citizens from Yemen of 30/03/2015 [online] 30/04/2015, https://www.youtube.com/watch?v=uw59BO1hEaE [access: 30/12/2019]. 
In Djibouti, the evacuees were transported by coach to a temporary accommodation organized at the Stade du Ville football stadium, where they awaited for transfer to their country of origin by passenger planes ${ }^{22}$.

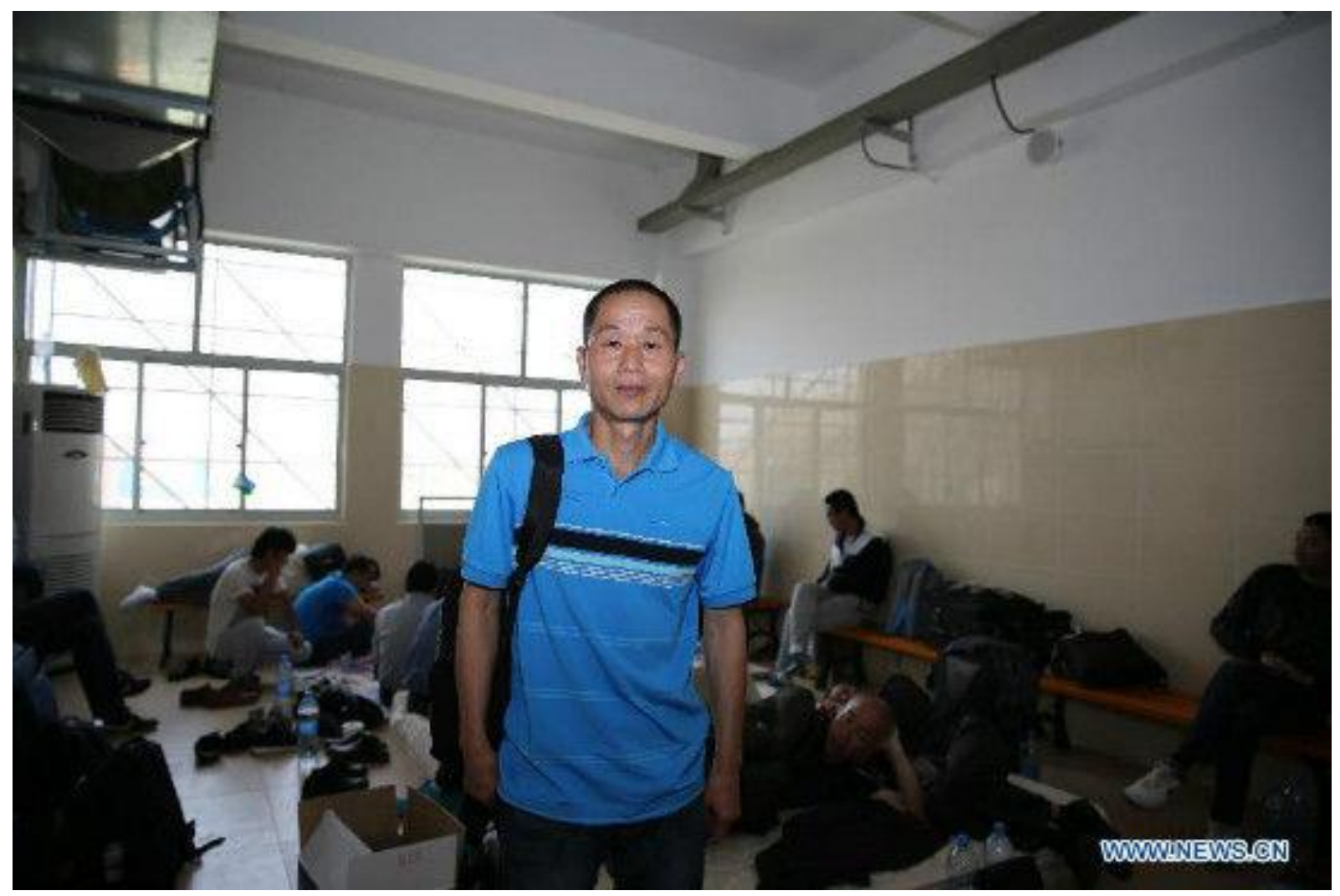

Fig 5. Evacuated Chinese citizens awaiting transfer to their country of origin. Djibouti 31 March 2015 Source: Xinhua Information Agency [online] 2015/04/01, http://english.sina.com/china/2015/0331/797157.html [access: 30.12.2019]

Although initially the Chinese authorities planned to evacuate only their own citizens ${ }^{23}$, after making sure they were already safe, it was decided to continue the operation and provide help to citizens of other countries, who found themselves in conditions of humanitarian crisis. In the result, on 3 April 2015, the Chinese missile frigate Linyi, in the third wave, evacuated 225 foreigners from Aden to the port of Djibouti ${ }^{2425}$. Among the evacuated citizens of 10 nations there were also 4 Poles $^{26}$.

${ }^{22}$ Over 500 Chinese evacuees from Yemen arrive Djibouti [online] 01/04/2015, http://english.sina.com/china/2015/0331/797157.html [access: 30/12/2019].

${ }^{23}$ B. Blanchard, China says completes evacuation of its nationals from Yemen [online] 31/03/2015, https://www.reuters.com/article/us-yemen-security-china/china-says-completes-evacuation-of-its-nationalsfrom-yemen-idUSKBNOMR0B420150331 [access: 30/12/2019].

24 A. Panda, China Evacuates Foreign Nationals from Yemen [online] 06/04/2015, https://thediplomat.com/2015/04/china-evacuates-foreign-nationals-from-yemen/ [access: 30.12.2019]. 


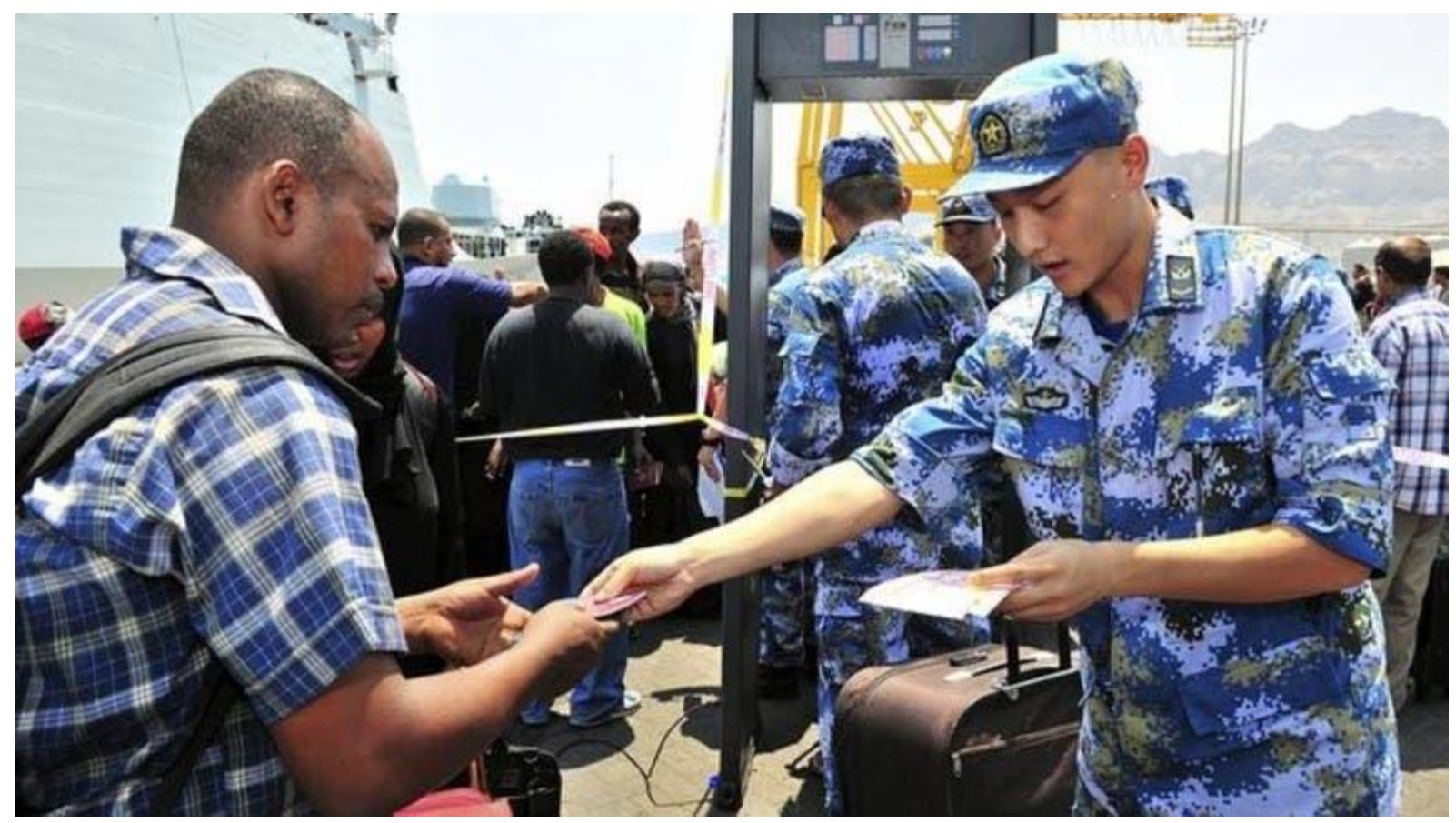

Fig 6. Security check organized by the Chinese Navy at the boarding point for evacuees. Aden port. 2 April 2015 Source: Reuters [online] 2015/04/07, http://english.alarabiya.net/en/News/middle-east/2015/04/07/Chinatemporarily-shuts-embassy-in-Yemen.html [access: 30/12/2019]

While, as a rule, China is trying to ensure the continuity of its diplomatic missions even during hostilities, the further escalation of operations in Yemen forced the Chinese authorities to temporarily shut down the Chinese Embassy in Sanaa and the consulate in Aden. Subsequently, on 7 April 2015, in the fourth wave, the Chinese ship Linyi evacuated the remaining 38 Chinese citizens from Yemen, including 14 members of the diplomatic staff. Additionally, at the request of the Sri Lankan government, 45 Sri Lankans found shelter onboard the Chinese frigate ${ }^{27}$.

\footnotetext{
${ }^{25} \mathrm{M}$. Rajagopalan, B. Blanchard, China evacuates foreign nationals from Yemen in unprecedented move [online] 03/04/2015, https://www.reuters.com/article/us-yemen-security-china/china-evacuates-foreign-nationals-fromyemen-in-unprecedented-move-idUSKBNOMU09M20150403 [access: 30/12/2019].

${ }^{26}$ Press release of the Ministry of Foreign Affairs of the Republic of Poland [online] 03/04/2015, https://www.msz.gov.pl/pl/p/msz_pl//aktualnosci/wiadomosci/ewakuacja_obywateli_polskich_z_jemenu [access: 30/12/2019].

${ }^{27}$ China helps evacuate 279 foreign citizens from Yemen [online] 07/04/2015, http://jp.xinhuanet.com/201504/07/c_134130164.htm [access: 30/12/2019].
} 


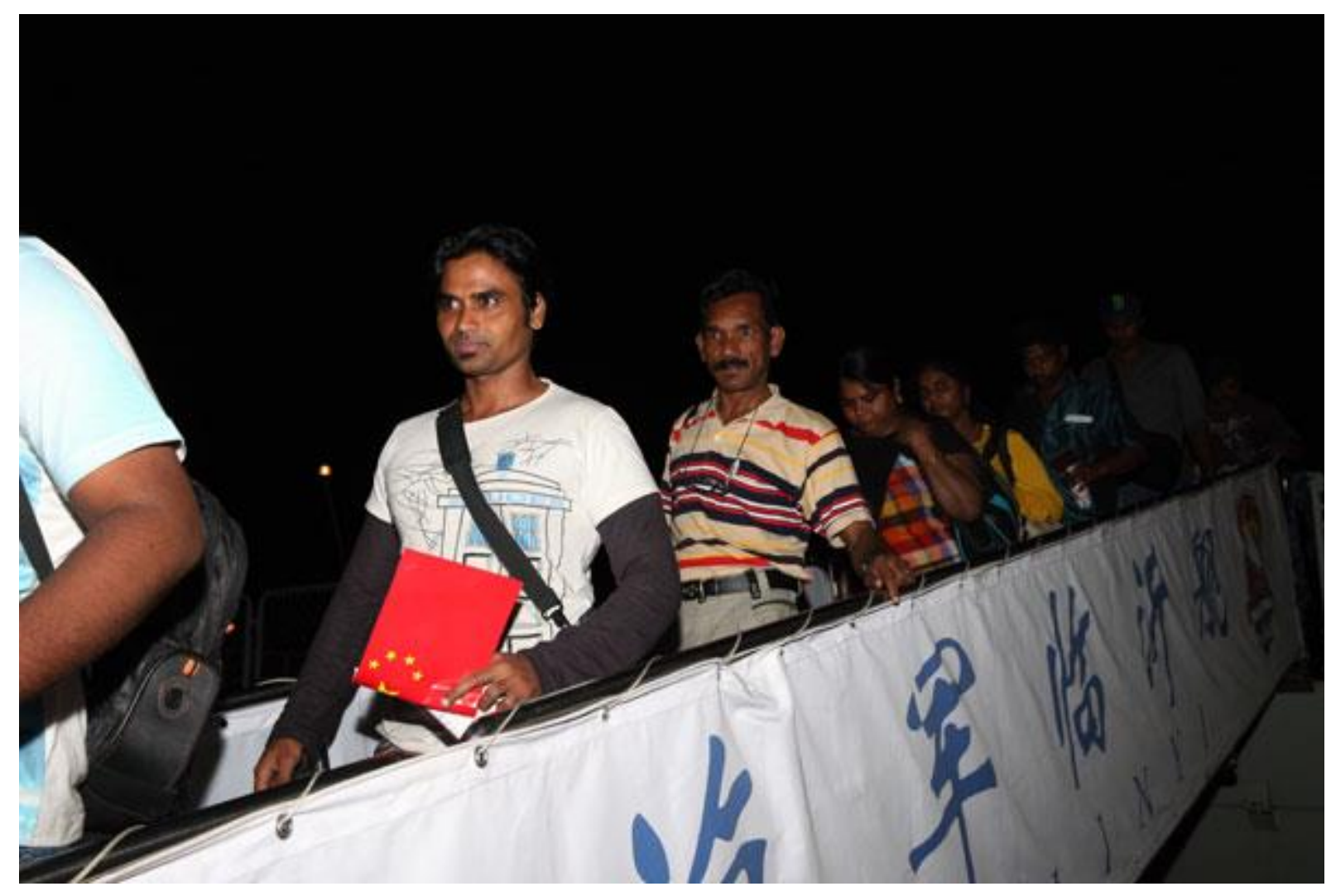

Fig. 7. Sri Lankan citizens disembark the Chinese ship at the port of Djibouti. 7 April 2015

Source: Xinhua Information Agency [online] 2015/04/07, http://jp.xinhuanet.com/2015-04/07/c_134130164.htm [access: 30.12.2019]

On the same day, the last nine Chinese citizens were evacuated by the Weishanhu supply ship. Its course demonstrates the spectrum of issues that may arise during an evacuation operation, and hence deserves a more detailed discussion. The aforementioned group consisted of seven members of a Chinese medical team from Socotra (the sole foreign team of this type providing medical assistance to local people) and two Chinese tourists ${ }^{28}$. On 5 April 2015, the Chinese embassy in Yemen notified Qin Tue, the head of the Chinese medical, that his team would be evacuated from Yemen as last. On the same day, the Chinese Foreign Minister Wang Yi announced that the team would be evacuated by the Weishanhu supply ship. Although the people scheduled for evacuation were not in immediate danger, the speed of action was important because the team's food supply only allowed them to maintain their existence for two further days. The next day Weishanhu made phone contact with the head of the medical team and details of the evacuation were agreed during some 30 phone calls. The lack of adequate port infrastructure prevented the Chinese ship from docking to the island's

${ }^{28}$ Success of 'Operation Red Sea' echoes Yemen rescue mission [online] 14/03/2018, http://www.chinadaily.com.cn/a/201803/14/WS5aa89339a3106e7dcc141963.html [access: 30/12/2019]. 
shores, therefore, according to the evacuation plans, the evacuation was to take place on the high seas, at a point located 17 miles from the island's shore. To get there, the Chinese medical team had to get the boat themselves, which was secured with help of Socotra's governor. Although the delivered vessel was not equipped with either a radio or GPS system, and the only navigation aid available to her captain was a monocular, he eventually managed to successfully bring the vessels together on the high seas ${ }^{29}$. The Chinese supply unit has taken nine Chinese and one Japanese citizen onboard. Then the whole group was transported to the port of Salalah in Oman, thus completing the active phase of evacuation from Yemen.

According to official Chinese data, during the operation, between 29 March and 7 April 2015, 629 Chinese citizens and 279 foreigners were successfully evacuated. Throughout the operation, no ${ }^{30}$ direct interaction of the fighting parties with the evacuated parties and the forces conducting the NEO operation was recorded.

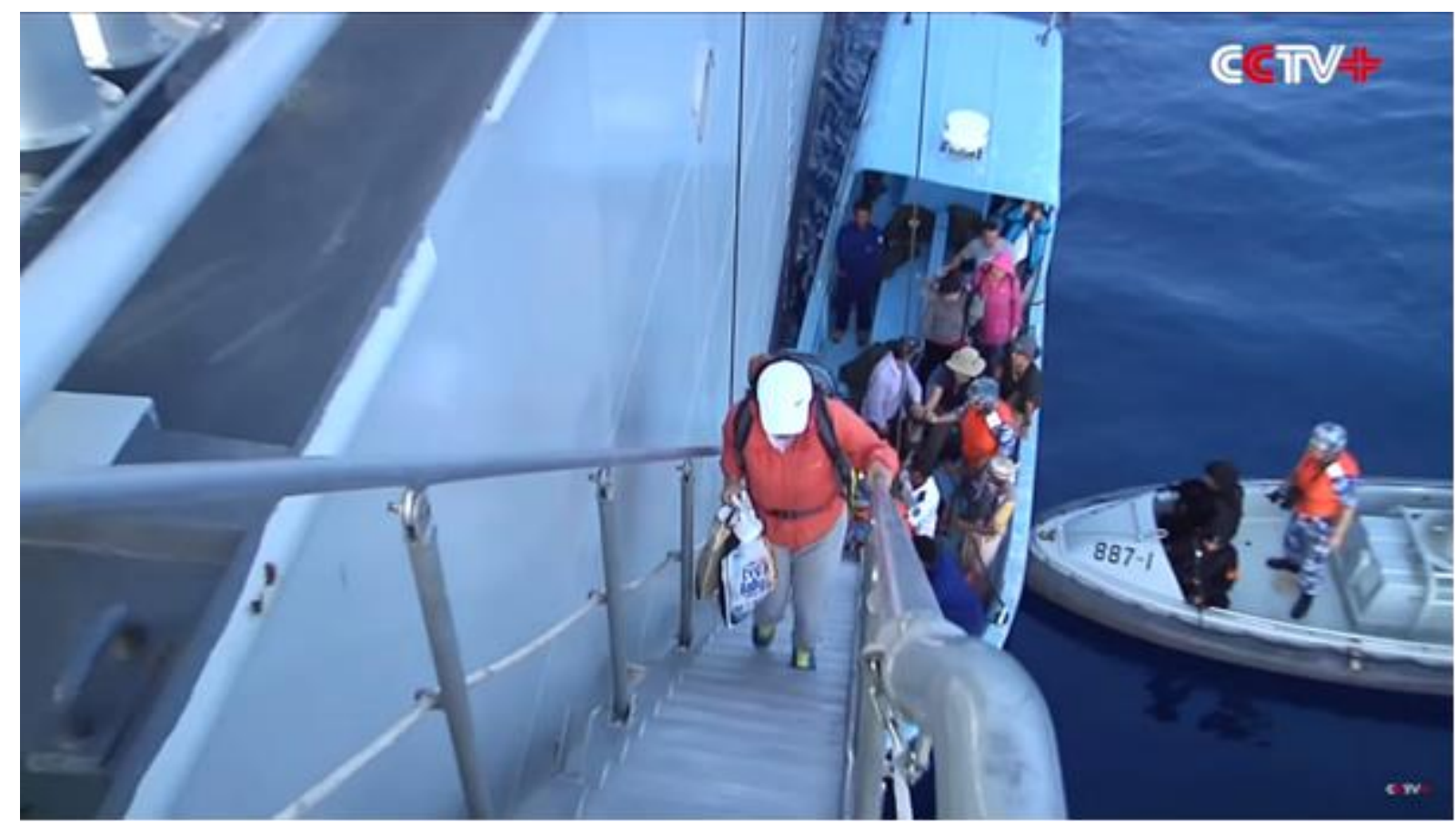

Fig. 8. Last Chinese citizens evacuated from Yemen on 7 April 2015 boarding the Weishanhu supply ship Source: China Central Television Story Behind Last Chinese Evacuation from Yemen of 10 April 2015 [online] 2015/04/10, https://www.youtube.com/watch?v=58YSsoBUohk [access: 30/12/2019]

\footnotetext{
${ }^{29}$ China Central Television coverage entitled Story Behind Last Chinese Evacuation from Yemen of 10 April 2015 [online] 2015/04/10, https://www.youtube.com/watch?v=58YSsoBUohk [access: 30/12/2019].

${ }^{30} \mathrm{With}$ the exception of one information, provided by Russia Today, and not confirmed by other sources.
} 


\section{Summary and conclusion}

It is beyond dispute that the evacuation operation carried out in Yemen by the Chinese army was a great organizational success. During the execution phase of the evacuation, the Chinese navy demonstrated professionalism in both planning of activities and their implementation. Effective evacuation made it possible to achieve objectives in three main areas:

1. Protection of Chinese international interests.

The growing activity on the international arena, which is manifested by the operation of Chinese diplomatic and trade representations in high-risk countries, forced China to develop efficient mechanisms (forces and procedures) for their evacuation. In a broader context, maintaining the abovementioned systems and periodically checking the effectiveness of their operations, as was the case in Yemen in 2015, gives China the opportunity to conduct diplomacy in unstable regions of the world, which translates into the efficient and uninterrupted implementation of strategic initiatives outside the borders of the Central State. The effective execution of the 2015 evacuation enabled the protection of diplomatic staff and employees of enterprises carrying out crucial economic undertakings abroad.

2. Acquisition and use of operational experience.

Multifaceted experience of navy of every maritime state forms the crucial element, and is required to construct forces with a global operational reach. The execution of the evacuation of own citizens in a hostile operational environment implied the performance of combat tasks within a separate task force operating in isolation from the national command centre. This created an unique opportunity, for the officers, mid-level commanders, as well as private soldiers (sailors) of the PRC to gather new experiences. At the same time, the subsequent actions of the Chinese political and military leadership indicate that the conclusions and experience gained as part of the operation were used to expand the existing logistics infrastructure, improve the organizational structure, and they were also incorporated in the training system. Everything indicates that the experience gained from Yemen, while not having a decisive influence, accelerated the decision of the Central Military Commission of the $\mathrm{PRC}^{31}$ to establish the first Chinese overseas military base. It is no accident that Djibouti was selected for its location ${ }^{32}$. At the same time, the internal structure of the Central Military Commission of the PRC itself was reorganized,

\footnotetext{
${ }^{31}$ Equivalent to the Ministry of Defense.
} 
creating the Overseas Operations Department in 2016. It took over the scope of activities in the area of command and coordination of overseas operations conducted by the Chinese army and it was also made responsible for readiness to detach rapid response forces $^{33}$.

The conclusions from the operation were also applied to the implementation of training projects. One of them was the joint Chinese-British staff training exercise "Joint Evacuation-2016", the scenario of which involved cooperation with international partners in the execution of NEOs ${ }^{34}$.

3. Building a positive image of Chinese authorities at home and abroad.

The successful evacuation of a significant number of own citizens was a great opportunity to prove the efficiency of state structures. It comes at no surprise that the Chinese media devoted a lot of attention to the evacuation. At the same time, helping other countries evacuate their vulnerable citizens from Yemen has received wide coverage throughout the world. China's actions were received not only as a demonstration of the efficiency of its diplomatic and military structures, but also as a great act of humanitarianism.

In addition to disseminating information concerning the successful course of the operation in local and international news channels, due care was also exercised to preserve this success in Chinese cinematography. The 2015 evacuation of Chinese citizens from Yemen in became the canvas for the movie entitled Operation "Red Sea". The film glorifies the activities of the Chinese army, and was presented to the local audience as a gift on the occasion of the ninetieth anniversary of the creation of the People's Liberation Army and the nineteenth congress of the Communist Party of China. The movie enjoyed enormous commercial success in the Central State, whereas abroad, even with the international distribution efforts, it failed to attract wider audiences ${ }^{35}$.

\footnotetext{
${ }^{32}$ It reached operational readiness shortly thereafter, in 2017.

${ }^{33}$ Y. Jianing, PLA sets up Overseas Operations Office to strengthen overseas rapid reaction [online] 25/03/2016, http://eng.chinamil.com.cn/news-channels/pla-daily-commentary/2016-03/25/content_6977517.htm [access: 30/12/2019].

${ }^{34}$ Ibidem.

${ }^{35} \mathrm{https}: / / w w w . b o x o f f i c e m o j o . c o m / r e l e a s e / r 13154478593 /$ [access: 30.12.2019].
} 


\section{References}

Amber, S.M., 1999. The Political and Economic Transformation of Yemen, 1968-1998. University of Durham.

Boucek, C., Johnsen, G.D., 2010. The Dilemma of the Yemeni Detainees at Guantanamo Bay. CTC Sentin.

Darwich, M., 2018. The Saudi Intervention in Yemen: Struggling for Status. University of Durham.

Hedberg, N.J., 2010. The exploitation of a weak state Al-Qaeda in the Arabian Peninsula in Yemen. Naval Postgraduate School in Monterey.

Orkaby, A.A., 2014. The International History of the Yemen Civil War, 1962-1968. Harvard University.

Rego, C., 2018. Effects of US Cold War Policy on the Modern State of Yemen: 1978 Through Unification and Civil War. the Harvard Extension School. 